\title{
The Emphasis of Inquiry Instructional Strategies: Impact on Preservice Teachers' Mathematics Efficacy
}

\author{
Krista L. Althauser ${ }^{1}$ \\ ${ }^{1}$ Eastern Kentucky University, Richmond, Kentucky, USA \\ Correspondence: Krista L. Althauser, Eastern Kentucky University, Richmond, Kentucky, USA. E-mail: \\ krista.althauser@eku.edu
}

Received: August 27, 2017

Accepted: September 11, 2017 Online Published: September 19, 2017

doi:10.5539/jel.v7n1p53

URL: https://doi.org/10.5539/jel.v7n1p53

\begin{abstract}
Using a Mixed Methods approach, this study investigated changes in levels of self-efficacy among elementary preservice teachers following a semester course on teaching elementary students' mathematics. Participants in this study included 347 preservice elementary teachers at a mid-size regional university who had just completed an elementary mathematics methods course. The data were collected from several semester groups. The instruments used were the Mathematics Teaching Efficacy Beliefs Instrument, interview data, and observation data collected during the clinical experience. The focus of this study was to compare the changes in teacher self-efficacy following a methods course that emphasized hands-on mathematics instruction with manipulatives by means of the $5 \mathrm{E}$ instructional format. The results of the paired-samples t-test indicated that there was a significant difference in the preservice elementary teachers' self-efficacy for teaching mathematics after engaging in the elementary methods course. Preservice teachers reported that their understanding of various instructional practices changed significantly from a "tell, show, and do" model to an approach utilizing interactive and engaging activities. They also reported that their attitude toward mathematics had improved significantly and that there had been a direct impact on their confidence for teaching mathematics as a result of the structure of the elementary math methods course.
\end{abstract}

Keywords: 5 E Inquiry, hands-on, manipulatives, mathematics, preservice teachers, self-efficacy

\section{Introduction}

The preparation of preservice elementary teachers to provide effective math instruction can be a challenging responsibility for any teacher education program, especially in today's society where it is acceptable to share sentiments of dislike, indifference, and failure in math. When listening to undergraduate students discuss their experiences in math, the conversations sound as though they have not only accepted their failures but are bragging about it. Elementary preservice teachers express higher levels of mathematics anxiety than other undergraduate majors (Cady \& Rearden, 2007; Harper \& Daane, 1998). They describe their negative views of mathematics such as "mathematics is my enemy" and "math is something I hate" (Cady \& Rearden, 2007). This mindset that failure in math is not only common, but acceptable and math is evil, must be addressed and a concentrated effort to eliminate it must be imposed if future generations of students are to improve in math achievement.

Teachers have more responsibilities on their plate now than in previous decades. Not only do teachers have to be experts in managing a classroom, but also have a repertoire of useful strategies readily available to provide useful complex information to diverse learners. All the while, preparing all students to achieve academic performance at higher than ever levels and establishing higher order thinking skills. Although math reform initiatives have generated much discussion about the structures of math instruction in teacher education programs (Ball \& Bass, 2000) there is minimal discussion of actually what goes on within the "black box" of the math courses, such as how does the class experiences add up to a set of mathematics knowledge, skills, and dispositions towards math that will one day determine what these future teachers will actually be equipped to teach in a classroom. Research on the factors contributing to student achievement in math repeatedly cite teacher expertise as one of the most important factors in determining student achievement (Ball, 1990; Ball, Thames, \& Phelps, 2008; Battista, 1999; Darling-Hammond \& Ball, 2004). 
Since 2000, math has taken center stage in education improvement initiatives, but regardless of current efforts in math reforms and the plethora of knowledge and information informing this work, there have not been significant changes in how the teaching and learning of mathematics occur in U.S. classrooms. Evidence from the Trends in International Mathematics Science Study, ranked the United States as fourteenth and showed the same average achievement as in previous years, indicting U.S. has become stagnant in mathematics achievement growth ([TIMSS] National Center for Educational Statistics, 2015). These results provide a warning that U.S. students still do not rank well compared to students of other nations with which the United States competes economically (Mullis, Martin, Foy, \& Hooper, 2016). The students' less than stellar performance in mathematics and the low numbers of students pursuing degrees in the STEM disciplines places the U.S. in a position that jeopardizes their global stance in the competitive economic market (Langdon, McKittrick, Beede, Khan, \& Doms, 2011).

It is apparent from years of unsuccessful reforms in mathematics education that teachers tend to teach only mathematics with which they are comfortable and evidence suggests that teachers in the U.S. lack essential knowledge for teaching mathematics. This lack of knowledge directly impacts how they teach mathematics (Ball, 1990; Ma, 1999). According to Blank and Langesen (2001), forty percent of elementary and middle school mathematics teachers do not feel qualified to teach their content and only seven percent of elementary teachers have minored or majored in mathematics education or mathematics. Many teachers report that they do not have sufficient conceptual understanding of mathematics and rely on rote computations and algorithms for instruction (Ball, Hill, \& Bass, 2005; Gerretson, Bosnick, \& Schofield, 2008; Newton, Evans, Leonard, \& Eastburn, 2012).

In the majority of teacher education programs, preservice teachers have many undergraduate experiences for which they must be successful. For example, teachers must take a college mathematics course (such as finite math or college algebra), one or two "mathematics for elementary teachers" courses, and also participate in general educational foundation/pedagogy courses in their college of education. However, it is not until the elementary mathematics course that students are often given the opportunity to make the connection between mathematics content and the pedagogical techniques that best support student learning (including their own). Unfortunately, preservice teachers are not likely to encounter the mathematics methods course until nearly the end of their undergraduate programs. As a result, preservice teachers are unlikely to report low self-confidence in their abilities to teach mathematics to children. This is further supported by their noted anxieties in conceptually understanding mathematics content (Vinson, 2001). Preservice teachers who experience math anxiety have a higher tendency to pass that anxiety on to their future students. It is important for preservice teachers to recognize the symptoms of math anxiety to see if they may have the potential of transmitting these negative attitudes to students. Negative attitudes can produce negative results in student achievement in mathematics.

\section{Literature Review}

This research is grounded in the intersection of four areas: 1) mathematics teaching anxiety research, 2) preservice teacher self-efficacy research, 3) Constructivist teaching research, and 4) use of manipulatives. Published work in each area supports the benefits of a mathematics course designed for preservice teachers to develop conceptual learning of math concepts through constructivist instructional strategies and provides a foundation to the research questions.

\subsection{Mathematics Teaching Anxiety}

Mathematics Teaching Anxiety is defined as one's feelings of tension and fear that takes place during the teaching of mathematical concepts (Levine, 1993; Peker, 2006). Mathematics teaching anxiety has a major role in how one would teach or introduce abstract concepts in a way more concrete or understandable for students. Often preservice teachers feel extremely nervous and unable to concentrate on their teaching due to their high level of mathematics teaching anxiety (Levine, 1993, 1996; Peker, 2006). These teachers shared that the situations which caused most anxiety for them was when they were asked to communicate their mathematical knowledge to others, whether in a test situation or in the teaching of mathematics such as that required in a practicum setting (Uusimaki \& Nason, 2004).

When preservice teachers expressed anxiety in their ability to teach mathematics, they shared that limited content knowledge and a deficient in in-depth understanding of math as the main causes (Bates, Latham, \& Kim, 2013). Studies focusing on math content knowledge show that many preservice teachers have a moderate level of procedural knowledge of mathematics and a very low level of conceptual knowledge (Vinson, 2001). This lack of knowledge lends itself to math anxiety that is directly related to the level of self-confidence of one's own mathematical skills. Self-confidence is defined as confidence in oneself and in one's powers and abilities. It is 
considered one of the most influential motivators and regulators of behavior in people's everyday lives (Bandura, 1986). Several researchers have suggested that one's perception of ability or self-confidence is the driving force of achievement strivings (Bandura, 1977; Nicholls, 1984). How people feel, think, motivate themselves and behave is determined by one's competence in self. The terms "self-confidence" and "self-efficacy" have been used concurrently to describe a person's perceived capability to accomplish a certain level of performance in many facets of life.

\subsection{Self-Efficiency}

Self-efficacy is defined as the beliefs people have about their capabilities to produce designated levels of performance that exercise influence over events that affect their lives (Bandura, 1993; Swars, Daane, \& Giesen, 2006). Mathematics teaching efficacy refers to one's beliefs in their ability to teach mathematics effectively (Enochs, Smith, \& Huinker, 2000).

Teachers are the crucial component to the success of the reform based on the research findings of the National Council of Teachers of Mathematics. Teacher implementation of effective instructional practices in mathematics has been linked to teacher self-efficacy (Battista, 1994; Savage, 2005).

Teachers' self-efficacy has been connected to teacher quality in that a teacher's quality of performance and commitment to work is related to his or her belief that effective teaching can bring about student learning regardless of external factors. Teacher self-efficacy is the extent to which a teacher feels capable to promote students learning in any content area. In the area of math instruction, teacher self-efficacy can affect instructional efforts in areas such as choice of instructional activities, level of effort, and persistence with students (Ware \& Kitsantas, 2007). Teacher efficacy has also been found to be associated with many powerful forces promoting a willingness to embrace innovative instructional strategies, such as, the use of successful hands-on mathematics activities including the use of manipulatives, and the use of meaningful text that contributes to a higher level of conceptual understanding that makes sense to students (Storm, 2007).

School is the place where children develop the cognitive competencies and gain the knowledge and problem-solving skills essential for participating effectively in the larger society (Bandura, 1993). The task of creating learning environments conducive to development of cognitive skills depends on the self-efficacy of teachers. Those who have a high sense of efficacy are more likely to use inquiry and student-centered teaching strategies that can motivate students. Teachers who have a low sense of selg-efficacy are more likely to use teacher-directed strategies, such as lecture and reading from a text which relies on negative sanctions to get students to study (Bandura, 1993).

Literature on teacher self-efficacy is abundant, however, there is limited research on mathematics teacher efficacy, specifically with elementary preservice teachers. If the expectation of current elementary preservice teachers is to teach future generations of students mathematics at high levels with results being an increase in student achievement, then more research is needed to better understand the potential impact of teacher education on teachers' instructional practices (Cochran-Smith \& Zeichner, 2005).

Self-efficacy is not simply a matter of how capable one is, but how capable one believes them self to be (Pajares, 2002). One way to raise self-efficacy beliefs is to improve mathematics instruction and reduce negative feeling toward math. As individuals have the capability to alter their own thoughts and feelings, their self-efficacy beliefs can powerfully influence their own teaching ability belief (Vinson, 2001).

It is believed that in order to facilitate the development of high efficacious mathematics preservice teachers, an in-depth exploration utilizing effective mathematics instruction should occur. Effective mathematics instruction is "learning in action" (Vinson, 2001). That action includes games, simulations, problem solving activities, discoveries, and challenges. Negative feelings toward math resulted from mathematics instruction lacking emphasis placed on the understanding of how math works, teaching that is detached from real-life experiences and paper and pencil drills (Vinson, 2001).

\subsection{Use of Manipulatives}

In recent years, the focus for mathematics instruction has changed direction from teacher centered to student centered (Ma, 1999). With the improvement of the Principles and Standards for School Mathematics (NCTM, 2000), it has become clear that standards-based mathematics teaching and learning is no longer a "one size fits all" approach (Putnam \& Borko, 2006). It has become a multi-faceted approach with many strategies to guide students in acquiring mathematical knowledge through problem solving with the use of manipulatives (Buns, 2007; Sowell, 1989). This has encouraged educators to study ways in which teaching and learning occurs in the 
elementary classroom, particularly when a primary goal is to teach students fluency and flexibility with numbers and strategies for using those numbers (NCTM, 2000).

Preservice teachers need instruction on making decisions regarding when and how to use manipulatives to guide students to think about their mathematical ideas more closely specifically exploration with concrete materials (Puchner, Taylor, O'Donnell, \& Fick, 2000; Stein \& Bovalino, 2001). This exploration is synonymous with inquiry-based tasks. The ability to interpret through observation of students' use of manipulatives is nearly as important as the mathematical thinking that the student can verbally communicate logically and clearly to teachers, peers, and parents (Cramer et al., 2002). Examples of where young children are using manipulatives in an inquiry based lesson, could be with the use of hundred boards, to learn algebraic concepts such as patterns and functions, or the use of drinking straws, to learn about the properties of angle, shape, and congruence in geometry. Both examples would help preservice teachers realize the connections between the manipulatives or other tools and the mathematical concepts being taught.

Naturally, most teachers seem to teach problem solving as a series of steps and/or in linear fashion, while most students need a full array of continuously supported opportunities to indirectly develop and improve problem solving techniques (Lambdin, 2003). It is important to consider varied strategies for guiding preservice teachers who are reluctant to embrace manipulatives and problem-based methods during instruction. When preservice teachers are reluctant to use perceived innovative, manipulative- and problem-based approaches, their personal perceptions of what mathematical problem solving and learning looked like in their own learning - most likely an abstract word problem or an algorithm written on the chalkboard, is the cause (Kelly, 2006).

According to Stein and Bovalino (2001), strategies for teaching and assessing problem solving with manipulatives all elementary teachers need to master are: 1) When, why, and how to use manipulatives effectively in the classroom through extensive training; 2) Using the same manipulatives to complete the same activities as will be ask of elementary students; and 3) Preparing the classroom for use of manipulatives by establishing a set of behavior expectations, organizing groups, preparing materials, and thinking through the logistics of the lesson.

To be better prepared to provide opportunities for all students to experience positive learning experiences in mathematics, preservice teachers need practice in effectively modeling manipulatives of all students transitioning from concrete objects to visual representation then to abstract notation. The Concrete-Representational-Abstract (CRA) method of instruction provides an effective format for teaching with manipulatives (Gerstein et al., 2009).

\subsection{Constructivism}

A constructivist approach to teaching, which encourages a deep learning approach on the behalf of the learner, promotes self-efficacy. Teachers create an environment in which they and their students are encouraged to think and explore mathematics. Constructivism leads to new beliefs about excellence in teaching and learning and about the roles of both teachers and students in the process (Steffe \& D'Ambrosio, 1995). In constructivist classrooms, students are active rather than passive; teachers are facilitators of learning rather than transmitters of knowledge. This active role ignites excitement for both teaching and learning mathematics in addition to strengthening teacher self-efficacy.

The emphasis of learning requires teaching with manipulatives and authentic learning situations that mimic mature situations of dealing with mathematics is encouraged. The experiences of the preservice teachers must be about the nature of teaching; combining the knowledge about mathematics with the knowledge about children and how they learn math. Preservice teachers are typically more apprehensive about teaching mathematics than any other subject. They need guidance to identify teaching practices that result in positive learning experiences such as; (a) hands-on approach using a variety of math manipulatives; (b) small groups and partner pair-share groups to discuss learning strategies and reflect on solutions to problems; (c) connection to children's literature; (d) technology to enhance student learning; (e) student led activities to demonstrate effective teaching strategies. In addition to teaching pedagogy, preservice teachers also need time to review content taught in a different way other than direct instruction. Meeting the challenge of reform-based teaching will require teachers to have deep insights about mathematics, about students as learners of mathematics and about pedagogy that will support students' learning.

Preservice Teachers need the opportunity to "unpack" the mathematical content they are going to teach, struggle with important mathematical ideas and explore the conceptual underpinnings and interconnections among topics (Hill, Loewenberg, Ball, \& Schilling, 2008). Situating teachers in a constructivist learning environment, wherein 
their thinking is the focus of thoughtful discussion and reflection, promotes transfer of learning to teachers' practice (Schifter, 1998).

Weiss, Pasley, Smith, Banilower and Heck (2003) argued that preservice teachers need a clear vision of effective instruction and advocate specific interventions to assist the realization of this vision to effectively guide the design and implementation of their lessons. These interventions include: 1) the opportunity to analyze high-quality lessons and identify the effective elements, 2) the use of textbooks and supplementary material designed to provide targeted instructional opportunities, and 3) being actively engaged in high quality learning opportunities with a focus on developing both content and pedagogical knowledge. Cohen and Hill (1998) found that engaging both preservice and in-service teachers in the reform-based curriculum and assessments resulted in both teacher growth and increases in student achievement.

Knowledge is constructed in social contexts. According to Steffe and D'Ambrosio (1995), constructivist teachers study the knowledge constructions of their students and interact with students in a learning space designed by, at least in part, the teacher's working knowledge of students' understanding of concepts and ideas. The definition implies that constructivist mathematics teachers listen to learners in ways that allow them to build a model of each learner's mathematical knowledge. Within this context, preservice teacher reflection is seen as an essential factor for constructing teacher knowledge, particularly teacher pedagogical knowledge (Wilson et al., 1987). A constructivist approach to teaching, which encourages a deep learning approach on the behalf of the learner, promotes self-efficacy. Post-Secondary Instructors of math need to create an environment in which they and their preservice teachers are encouraged to think and explore mathematics. Constructivism leads to new beliefs about excellence in teaching and learning and about the roles of both teachers and students in the process (Steffe \& D'Ambrosio, 1995).

\section{Purpose and Research Questions}

1) Did the elementary math methods course with the use of inquiry-based instructional strategies effect the preservice teachers' self-efficacy with teaching math?

2) Did the use of manipulatives have an effect on the preservice teachers' self-efficacy?

\subsection{Theoretical Framework}

The framework serves to define the investigation of the elementary math methods course work and is based on the principles of effective reform based mathematics instructional strategies, efficacy theory, and constructivism. Based on the research findings of Cayci (2011), those teachers who have positive attitudes towards the teaching profession convey themselves to be better prepared to teach children. Preservice teachers of elementary mathematics also need to have positive attitudes towards the teaching of mathematics to be effective teachers. Effective teaching that leads to student achievement requires teachers to possess the knowledge of strong pedagogy and engage in classroom practices that relate to mathematical content, pedagogy, child development and student thinking in an integrated way. This framework was developed to design and implement the elementary math methods course that addresses these practices.

Firestone, Mangin, Martinez and Polovsky (2005) stated that successful content knowledge training consists of the subject matter being presented in a classroom friendly form that includes materials, examples, and student activities. Research on effective instructional practices for mathematics teachers echoed the same essential elements as effective instructional practices in general. Opportunities to incorporate these concepts and suggestions into their daily teaching are also critical (Firestone et al., 2005). Mathematics teacher training should also concentrate on pedagogical strategies that require preservice teachers to manipulate materials and ideas in order to explore concepts and make connections between ideas. According to Firestone et al. (2005), teachers should be introduced to a set of activities, materials or ideas and then be given the opportunity for practice and reflection. The learning opportunities for preservice teachers should model the instructional strategies they are expected to use. To be effective, these activities and strategies should represent an integral part of the teachers' daily practice rather than additional tasks.

The National Council of Teachers of Mathematics (NCTM) stressed the importance of focusing on high standards and in-depth learning opportunities for preservice teachers (NCTM, 2012). To ensure that all students have the opportunity to receive high quality mathematics instruction, learn challenging grade level content, and receive the support necessary to be successful, preservice teachers need instruction on the standards for teaching and learning math. These standards are grouped in three categories: 1) Knowledge; 2) Implementation; 3) Analysis. These are essential to defining what goes on in math classrooms (NCTM, 2007). 
What this means for university programs that prepare preservice teachers, is that the math instructional courses must have content knowledge for each math concept as well as pedagogical knowledge interwoven in each math class. In addition, an understanding of how all students learn math is an important thread needed in the courses, to prepare preservice teachers to be able to guide students to a conceptual understanding of mathematics, to implement worthwhile tasks and design learning activities that are challenging, yet support the learning environment, and promotes mathematical discourse among all members of the learning community. Finally, the importance of fostering the development of every child's mathematical proficiency and understanding through on-going monitoring of classroom tasks, activities, discourse, and the learning environment must be threaded throughout the instructional process of each course. Through instructional activities, focused on how to analyze both formative and summative assessments, preservice teachers will receive direction on how to make future instructional decisions for their students and equip them with the knowledge of how to examine the relationship between what they are doing (instruction) and what the students are learning.

\subsection{Context of the Study}

The elementary math methods course provided focus on both mathematics content and mathematics knowledge for teaching. Emphasis upon the reform vision of the National Council of Teachers of Mathematics (NCTM, 1991), learning to provide effective instruction in the five content standards; (a) number operations, (b) geometry, (c) measurement, (d) data analysis and measurement, (e) algebraic reasoning and how each of the content areas intertwine with each other in overall instruction. The lesson planning development was designed around constructivist learning principles, with an emphasis on problem solving with the development of conceptual understanding. The preservice teachers also received explicit instruction on a variety of effective mathematics teaching strategies including intervention strategies for struggling students. The math methods course focused on concrete learning of mathematics content by use of manipulatives which also supported the research that was shared with the preservice teachers. These concrete experiences contributed to the preservice teachers having a stronger conceptual understanding of the mathematical concepts as well as helping them to focus on the importance of guiding students to understand the meaning of their answers to math problems (Carpenter, Fennema, \& Franke, 1996).

Each class was set up using the 5E Instructional format. The sequence of stages (Engage, Explore, Explain, Extend, Evaluate) are used to organize instruction. These stages guide students to full understanding of lesson content. This instructional model promotes a constructivist approach to math education. Constructivism stems from the work of Jean Piaget, and promotes the idea that people construct knowledge and meaning from experiences. Through processes and assimilations (provided by the instructor) people incorporate new ideas by changing or accommodating their understanding to fit the new information. Educational movements, such as inquiry-based learning, active learning, experimental learning, discovery learning are variations of constructivist learning. In a constructivist model, the teacher acts as a facilitator rather than the source of knowledge. The concept behind the $5 \mathrm{E}$ Instructional Model is to begin with students' current knowledge, make connections between current and new knowledge, provide instruction of ideas the students would not be able to discover on their own, and provide opportunities to demonstrate understanding (Bybee, 2006). In summary, the 5E Instructional Model involves teachers encouraging students to think and explore mathematics using hands-on activities with the use of manipulatives to construct meaning. Students are organized to work in groups, discuss ideas, and construct knowledge gained from their peers.

Table 1. Summary of the 5E Instructional Model

\begin{tabular}{ll}
\hline $\begin{array}{l}\text { Engagement } \\
\begin{array}{l}\text { Students Access prior learning and make connections to new } \\
\text { knowledge. }\end{array}\end{array}$ & $\begin{array}{l}\text { The teacher activates prior knowledge to discover student } \\
\text { preconceptions or misconceptions. Effective instruction must take } \\
\text { into consideration the knowledge that students currently have. }\end{array}$ \\
$\begin{array}{l}\text { Explore } \\
\text { Challenges student preconceptions by connecting new knowledge }\end{array}$ & $\begin{array}{l}\text { Teacher initiates hands-on opportunities for exploration to } \\
\text { investigate a math concept. Teacher observes by listening and asking } \\
\text { probing questions, is the "guide on the side" will redirect or provide } \\
\text { guidance when needed. }\end{array}$ \\
$\begin{array}{l}\text { Explain } \\
\text { Students explain their understanding of what they learned in the } \\
\text { explore stage. Teacher has opportunity for input if concerned } \\
\text { missed the point of the lesson, experienced cognitive overload, or }\end{array}$ & $\begin{array}{l}\text { Teacher provides opportunities for students to explain their thinking } \\
\text { on the hands-on opportunity provided in the explore. Allows }\end{array}$ \\
\hline
\end{tabular}


developed misconceptions.

\section{Extend}

Extending or elaborating on content to increase complexity of the concept.

Evaluate

Provides information on student learning.
Teacher provides a higher-level learning opportunity to explore the same math concept introduced earlier.

Formative (used during the lesson) or summative (at end of lesson or unit)

Each class began with deconstructing the math standard(s) being covered that day. Preservice students "unpacked" the standards and discussed the content and learning trajectories for students at different grade levels. Strengthening preservice teachers' understanding of individual grade-level standards enhanced their awareness of how content is developed across the grades. By increasing focus through the important areas at each grade level or additional coherence through these carefully developed connections within and across grades, the preservice teachers learned how to use standards to support their curriculum selections and choices for instructional activities (Dacey \& Polly, 2012). The standards were deconstructed into a set of learning targets and clearly aligned to the assessment. The learning targets were then worded in teacher-friendly language and student-friendly language. Lesson planning using the $5 \mathrm{E}$ format followed, addressing the math concept indicated in the deconstructed standard.

For the engage stage, preservice teachers were introduced to using children's literature to present children to math content. By integrating literature into mathematics, preservice teachers learn to: (a) create relevance, (b) increase motivation, (c) promote critical thinking, and (d) improve problem solving skills through the use of literature examples (Moyer, 2000; Murphy, 1999). Hands-on activities were also shared as a way to engage all students in the content equitably (Turner, Drake, McDuffie, Aguirre, Bartell, \& Foote, 2012). Preservice teachers were introduced to how the "minds-on" factor is a piece of the "hands-on" equation and how to assess students" prior knowledge when they are fully engaged in a task, they are actively doing and actively thinking.

For the explore stage, preservice teachers were actively engaged in activities to reexamine the standard(s) they previously deconstructed. These activities included mimicking actual teaching episodes to model the instructional progress. In order for preservice teachers to be prepared to teach mathematics for high standards, they need to not only know what the standards are, but they must also understand what the standards mean (Ball, 1996). These activities also helped to increase the preservice teachers' mathematics content knowledge, uses of research-based pedagogy, and effective use of formative assessment strategies to develop the preservice teachers to their fullest teaching potential (Wilson, Floden, \& Ferrini-Mundy, 2002). While hands are engaged, minds should be questioning, sorting through sensory input, and making connections. Vinson (2001) found that when preservice teachers were involved in hands on instruction through the use of manipulatives, constructivism, literature, and other problem-solving activities, the effective instruction helped make mathematics meaningful.

The explain stage in each lesson covered in class, proved to be a crucial time for the preservice teachers. This part of the lesson was designed for them to explain their understanding of the problem-solving strategies they used during the activity presented in the explore stage of the lesson. It is at this time where they are given time to talk with their peers, share their reflections, and discuss the different strategies used to teach the different concepts. It is during this time that the "A-ha moments happened", and the realization that a "one-size, fits all" approach is not what is best for students. Discussions began to erupt on how to differentiate activities to meet the needs of all learners.

Higher order learning opportunities are what was provided in the extend stage. The intentional use of technology to enhance instruction of the standards was a popular choice. According to Herron (2010) preservice teachers' struggles with technology in the classroom because they don't feel prepared to use technology in their mathematics teaching. Teacher education programs have a responsibility to prepare future teachers to effectively use technology in mathematics instruction. The National Council of Teachers of Mathematics (NCTM) technology principle states, "Technology is essential in teaching and learning mathematics; it influences mathematics that is taught and enhances students' learning" (NCTM, 2000). The use of web resources, design of blogs, and use of iPads were introduced during the extend stage. Preservice teachers were required to complete one project on one technology tool to be used in future math instruction. In addition, higher-order problem solving activities that increased the complexity of the concept were introduced and practiced in class. 
During the evaluate stage, the preservice teachers, with the help of the instructor, developed appropriate formative and summative assessments that aligned with the standard(s). Using Stephens and Lamers (2006) approach to assessment design for preservice teachers, the instructor first, addressed the importance of aligning the assessments with their intended purposes. The preservice teachers worked in small groups planning the assessment. Once the assessments were designed, they were modeled in the classroom where all preservice teachers participated. Input was solicited from the class on the accuracy of the alignment to the standard. Second, the instructor discussed the limitations of a single assessment. For example, a think-pair-share exercise was modeled highlighting how various strategies were used to solve one problem. Preservice teachers learned how formative assessment can provide teachers and students with additional information about what students understand and where students' have misconceptions. These pieces of student information are commonly missed when only using standardized summative assessment consisting of multiple choice questions. Finally, the instructor emphasized the various purposes that assessments have in the classroom. In addition to grades on assigned learning, assessments can offer insight into students' conceptions and misconceptions and inform future teaching procedures. The preservice teachers also learned how to implement formative assessment in their daily instruction and how to use it to guide future instruction to improve all student learning (Rizzo, 2010).

Upon completion of all coursework, the preservice teachers participated in a 5-week long field experience with a cooperating elementary teacher. This field experience consists of three days a week ( 15 days) for 8 hours each day. Preservice teachers work alongside of their cooperating teacher, planning and teaching lessons (small group and whole group), working with individual struggling students, organizing materials for instruction, managing classroom behavior, and attending meetings with the Professional Learning Communities (PLC). Assuming the preservice teachers successfully complete the requirements, they then proceed to a full semester of student teaching.

\section{Methodology}

\subsection{Sample}

The study involved 347 elementary preservice teachers at a mid-size regional university. The preservice teachers at this university, were required to complete three math content courses focused on numbers and operations in integers and rational numbers and geometry. The fourth course, the elementary math methods course, focused on both mathematics content and mathematics knowledge for teaching, the use of common lesson planning designed using constructivist learning principles, strong emphasis on problem-solving and the development of early numeracy with conceptual understanding. The participants were also involved in clinical experiences with a university supervisor and cooperating teacher in a local elementary school. The participants experienced several opportunities to teach math lessons and utilize pedagogical techniques learned in the math methods course. The participants spent a total of 15-18 days in their clinical placements.

\subsection{Research Design}

The purpose of this study was to investigate the effect a semester mathematics course designed to implement hands-on inquiry instructional strategies using manipulatives would have on teachers' self-efficacy towards teaching mathematics.

This study used a mixed method approach using triangulation of the data. The primary data sources consisted of the Math Teaching Efficacy Survey, teaching observations, and individual interviews. All data sources were triangulated for reliability, by cross-checking the data collected through observations at different times and in different classrooms, interview data collected from different preservice teachers, and the results from the self-efficacy survey. The results were used to document the preservice teachers' use of reform-based instructional practices, preservice teachers' attitudes and beliefs and the impact the course design had on preservice teachers' attitudes towards mathematics and their behavior during math instruction.

\subsection{Data Sources}

Math Teaching Efficacy Beliefs Inventory (MTEBI). This instrument was adapted from Science Teaching Efficacy Beliefs Statement (STEBI). Riggs (1988) developed and validated this instrument to measure teacher's personal self-efficacy and outcome expectancy beliefs for science teaching and learning. It included questions answered with a likert scale as well as open ended questions. A comparable instrument for mathematics was not found. The open-ended questions were adapted and administered to 347 participants at the beginning and ending of the elementary method course over six-semester span. 


\subsection{Observations}

Participant observation is an attempt for the researcher to see the instruction through the eyes of the students who are in the classroom. Denzin and Lincoln (2005) describe participant observation, as "grounded in the establishment of considerable rapport between the researcher and the host community and requiring the long-term immersion of the researcher in the everyday life of that community" (p. 732). Direct involvement in the daily lives of teachers and students provides researchers a point of reference for the logic and process of participation in observational inquiry. In addition, this strategy is most appropriately used for gaining access to phenomena that are commonly obscured from the standpoint of the non-participant. The researcher generates practical and theoretical truths about the participants and their daily existence. By taking on the role as a participant observer, researchers can conduct observations in a fairly unobtrusive method and look only at material that is pertinent to the issue at hand such as math instructional strategies. For this study, a total of twelve participants were observed for a 60-minute math lesson over a six-semester span. The twelve were chosen at random, to direct the researcher, an observation guide was created reflecting what was taught in the course based on the course syllabus. The following protocol guided the inquiry in each of the twelve classrooms observed and provided a structure for keeping data aligned.

Table 2. Observation guide

1. Use a common observation tool with clear, straightforward language and observable, measurable actions.

a. Use of hands-on manipulatives

b. Instructional Practices chosen

c. Formative Assessment Strategies used

d. Strategies used to promote problem solving

e. Student engagement during instruction and group or independent work

f. Strategies used for struggling math students and differentiation practices

2. Review lesson plans and collect student work samples to determine impact.

3. Observe classrooms as one group, not a series of smaller parties.

\subsection{Individual Interviews}

In qualitative research, an interview is the basic tool used as an effort to understand the teachers' point of view, and to find out what the participants have experienced. When interviews are conducted, it is assumed the subjects have meaningful information to share. This method captures the meaning of participants' perceptions and experiences in their own words. This study combines other techniques to triangulate the data for reliability and validity (Denzin \& Lincoln, 2000). For this study, twelve Individual semi-structured interviews were conducted with the same twelve participants represented in the observations.

Table 3. The interview outline

1. What have you learned as a result of the elementary mathematics methods course on the use of math manipulatives; formative assessment strategies; and intervention strategies?

2. What have you learned that has impacted your beliefs about your instructional practices?

3. What have you learned about how the new instructional approaches impact student learning?

4. What have your learned that has helped you to differentiate your math instruction for all students?

\section{Analysis of Data}

Efficacy changes towards teaching math among preservice elementary education teachers during teacher education methods class were analyzed. To respond to Question 1, the study employed a paired-samples $t$ test to compare the means of the same measurement of preservice teachers' math teaching efficacy before and after a math methods course from the MTEBI. A paired samples $t$ test is used when the same individual needs to be measured twice, usually in a before-after or pretest-posttest design (Harris, 1997). 


\subsection{Analysis of Qualitative Data}

Analytical Coding was used to analyze the qualitative data. Analytical coding is intended to aid in understanding of the interpretation and reflection on meaning in data through the development of summary themes or categories from the raw data (data reduction) (Thomas, 2006). The themes were titled, "Changes in content knowledge and standards"; "Changes with Instructional strategies"; "Changes with student engagement"; "Concerns with struggling students and those with special needs".

\subsection{Results and Discussion}

To compare the pre- and post-test scores, the results were analyzed using paired samples t-test. The analysis revealed a significant difference between the pre- and post-test scores $(t=12.45, p=.000)$. Each teacher's pre-and post-results were specifically linked to one another. The dependent variable in this study is Math Teaching Efficacy, which was assessed by 24 items with high internal consistency and thus reliability $(=.981)$. The surveys used a 6-point Likert scale ( $1=$ Strongly agree, 2=Agree, 3=Barely agree, 4=Barely disagree, 5=Disagree, $6=$ Strongly disagree). The means and standard deviations of the pre-and post-survey are listed in descending order below in Tables 1 and 2. Not surprisingly, the preservice teachers reported the highest levels of efficacy teaching lower level math concepts such as addition and subtraction, and the lowest levels of efficacy teaching more complex concepts such as statistics, probability, percentages, decimals and fractions. They also reported relatively low levels of comfort with the principal evaluating their teaching, an important finding given this states implementation of a new high stakes teacher effectiveness assessment system.

Table 4. Math teaching efficacy pre-test items from high to low efficacy

\begin{tabular}{|c|c|c|c|}
\hline \multicolumn{4}{|c|}{ Descriptive Statistics } \\
\hline & $\mathrm{N}$ & Mean & Std. Deviation \\
\hline I am able to teach the topic of addition. & 347 & 2.92 & 1.910 \\
\hline I am able to teach the topic of subtraction. & 347 & 2.94 & 1.899 \\
\hline I am able to teach students how to measure with a ruler. & 347 & 3.00 & 1.892 \\
\hline I am able to help students learn how math is relevant to everyday life. & 347 & 3.15 & 1.640 \\
\hline I am able to teach the topic of multiplication. & 347 & 3.16 & 1.709 \\
\hline I am able to teach the topic of math to everyday life. & 347 & 3.18 & 1.620 \\
\hline I look forward to teaching math. & 347 & 3.19 & 1.640 \\
\hline I am able to teach the topic of division. & 347 & 3.19 & 1.707 \\
\hline I am able to use technology in my math teaching. & 347 & 3.27 & 1.584 \\
\hline I am able to answer students' questions about math. & 347 & 3.29 & 1.403 \\
\hline I am able to teach the topic of decimals. & 347 & 3.39 & 1.467 \\
\hline I am able to teach the topic of percents. & 347 & 3.39 & 1.471 \\
\hline I am able to teach math problem solving skills. & 347 & 3.40 & 1.353 \\
\hline I am as able to teach math as I am able to teach language arts. & 347 & 3.42 & 1.455 \\
\hline I am able to teach the topic of fractions. & 347 & 3.42 & 1.487 \\
\hline I am able to teach students how to communicate about math topics. & 347 & 3.46 & 1.293 \\
\hline I am able to teach the topic of word problems. & 347 & 3.50 & 1.429 \\
\hline I am able to teach the topic of algebraic reasoning. & 347 & 3.56 & 1.349 \\
\hline I am able to teach the topic of geometry. & 347 & 3.56 & 1.410 \\
\hline I am able to reduce students' math anxiety. & 347 & 3.56 & 1.316 \\
\hline I know steps necessary to teach math concepts effectively. & 347 & 3.65 & 1.333 \\
\hline I am comfortable the principal evaluate my math teaching. & 347 & 3.72 & 1.332 \\
\hline I am able to teach the topic of statistics. & 347 & 3.80 & 1.342 \\
\hline I am able to teach the topic of probability. & 347 & 3.81 & 1.355 \\
\hline Valid N (listwise) & 347 & & \\
\hline
\end{tabular}


Table 5. Math teaching efficacy post-test items from high to low efficacy

\begin{tabular}{|c|c|c|c|}
\hline \multicolumn{4}{|c|}{ Descriptive Statistics } \\
\hline & $\mathrm{N}$ & Mean & Std. Deviation \\
\hline I am able to teach the topic of addition. & 347 & 2.66 & 2.037 \\
\hline I am able to help students learn how math is relevant to everyday life. & 347 & 2.66 & 1.856 \\
\hline I am able to teach the topic of math to everyday life. & 347 & 2.67 & 1.886 \\
\hline I am able to teach the topic of subtraction. & 347 & 2.68 & 2.038 \\
\hline I am as able to teach math as I am able to teach language arts. & 347 & 2.69 & 1.616 \\
\hline I am able to teach the topic of geometry. & 347 & 2.70 & 1.594 \\
\hline I am able to teach students how to communicate about math topics. & 347 & 2.73 & 1.610 \\
\hline I am able to reduce students' math anxiety. & 347 & 2.73 & 1.578 \\
\hline I am able to teach students how to measure with a ruler. & 347 & 2.74 & 1.955 \\
\hline I am able to answer students' questions about math. & 347 & 2.75 & 1.632 \\
\hline I am able to teach the topic of multiplication. & 347 & 2.75 & 1.808 \\
\hline I am able to use technology in my math teaching. & 347 & 2.75 & 1.696 \\
\hline I look forward to teaching math. & 347 & 2.75 & 1.721 \\
\hline I am able to teach the topic of division. & 347 & 2.76 & 1.784 \\
\hline I know steps necessary to teach math concepts effectively. & 347 & 2.76 & 1.621 \\
\hline I am able to teach the topic of word problems. & 347 & 2.76 & 1.590 \\
\hline I am able to teach math problem solving skills. & 347 & 2.79 & 1.560 \\
\hline I am able to teach the topic of algebraic reasoning. & 347 & 2.82 & 1.551 \\
\hline I am comfortable the principal evaluate my math teaching. & 347 & 2.86 & 1.556 \\
\hline I am able to teach the topic of statistics. & 347 & 2.91 & 1.426 \\
\hline I am able to teach the topic of probability. & 347 & 2.92 & 1.445 \\
\hline I am able to teach the topic of fractions. & 347 & 2.94 & 1.621 \\
\hline I am able to teach the topic of percents. & 347 & 2.94 & 1.576 \\
\hline I am able to teach the topic of decimals. & 347 & 2.95 & 1.589 \\
\hline Valid N (listwise) & 347 & & \\
\hline
\end{tabular}

To determine if there was a difference between Math Teacher Efficacy between the pre and post-means, a paired samples t-test was run. The pre Math Teacher Efficacy mean was 3.37, and the post Math Teacher Efficacy Mean was 2.78. The results of the t-test presented in Table 3 indicate that Math Teacher Efficacy at the end of the course was high than prior to the start of the course $(\mathrm{t}=12.45, \mathrm{p}=.000)$. Furthermore, $78.1 \%$ of the preservice teachers reported higher levels of Math Teacher Efficacy at the end of the course. However, overall Math Teacher Efficacy levels indicate that preservice teachers report only slightly better than a mean of 3, which represents "barely agreeing" with the items on average.

Table 6. Paired samples t-test of pre and post math teacher efficacy

\begin{tabular}{|c|c|c|c|c|c|}
\hline \multicolumn{6}{|c|}{ Paired Samples Statistics } \\
\hline & & Mean & $\mathrm{N}$ & Std. Deviation & Std. Error Mean \\
\hline \multirow[t]{2}{*}{ Pair 1} & Math Teaching Efficacy Pre-Test & 3.3728 & 347 & 1.27931 & .06868 \\
\hline & Math Teaching Efficacy Post-Test & 2.7785 & 347 & 1.56259 & .08388 \\
\hline
\end{tabular}




\begin{tabular}{|c|c|c|c|c|c|c|c|}
\hline \multicolumn{8}{|c|}{ Paired Samples Test } \\
\hline & & \multicolumn{3}{|c|}{ Paired Differences } & \multirow[b]{2}{*}{$\mathrm{t}$} & \multirow[b]{2}{*}{ df } & \multirow[b]{2}{*}{ Sig. (2-tailed) } \\
\hline & & Mean & Std. Deviation & & & & \\
\hline Pair 1 & $\begin{array}{l}\text { Math Teaching Efficacy Pre-Test - } \\
\text { Math Teaching Efficacy Post-Test }\end{array}$ & .59438 & .88906 & .04773 & 12.454 & 346 & .000 \\
\hline
\end{tabular}

At the beginning of the methods course, preservice teachers' self-reporting of their perceived instructional practices and beliefs on the survey instrument indicated that, collectively, the preservice teachers thought that overall, they might be good mathematics teachers (3.37). However, their understanding of what constituted effective mathematic teaching was consistent with traditional teaching practices that were used while they were students in elementary school, which are not substantiated by research and are in direct opposition to the recommendations of $\operatorname{NCTM}(1991,2000,2006)$. The instructional strategy of telling mathematics, demonstration, and rote practice are no longer acceptable (Battsta, 1999; Goos, 2004). At the end of the course, the preservice teachers reported a slight gain in their efficacy, only barely agreeing they would be good teachers of mathematics (2.78). Further investigation utilizing qualitative research methods was conducted to gather additional insight into preservice teachers' attitudes and beliefs on implementing reform-based instructional practices, the impact the course design had on their behavior during math instruction, and overall teaching self-efficacy.

\subsection{Preservice Teachers' Views about Their Changing Efficacy on Teaching Mathematics}

Data analysis of the observation and interview data consisted of analytical coding. Analytical coding comes from interpretation and reflection on meaning (Richards, 2005). The coding process involves relating categories that arise and the properties to each other. Refining the scheme for the themes. The analytical coding of the observation and interview data resulted in the following themes: (1) content knowledge and standards; (2) Instructional strategies; (3) student engagement; (4) struggling students and those with special needs. The following section will present the data and findings as organized under these themes.

\subsection{Content Knowledge and Standards}

An analysis of the interviews and observations indicated that all twelve of the preservice teachers found the elementary methods course to be rewarding as it provided them with a deeper knowledge of the mathematics content and standards. All preservice teachers observed, listed the deconstructed math standard on the board and worded it using the student friendly "I can" format. Examples from classrooms include, "I can count to 50"; "I can draw an array to multiply numbers"; "I can skip count to 100 by $2 \mathrm{~s}$ ".

Additionally, all twelve of the preservice teachers greatly valued being able to participate in the teaching activities they would possibly be using, stating that it helped them learn math differently and their content knowledge strengthened. They reported that their prior experiences as a learner of mathematics entailed performing computations following specific procedures and algorithms and the memorization of facts. Prior to the methods class sessions, they were not taught that a problem could be solved using a variety of approaches or that one could apply logic and reasoning to solve a challenging problem. This newly gained content knowledge was evident in their lessons, the preservice teachers were observed initiating active learning using manipulatives, for students to construct meaning rather than just memorizing procedures, algorithms or completing a worksheet. As a result of this class, the preservice teachers reported the value in developing the understanding of the big ideas of mathematics and the connections between math concepts. Three of the twelve preservice teachers reported that they never realized the connections between time, money and measurement with number operations - they saw these as discreet topics that could only be taught by themselves, until we covered them in class. These three teachers were observed teaching money, time, and measurement with counting by 5's classrooms. Overall, preservice teachers reported that the class sessions provided them with a deeper understanding of the math concepts they would be teaching and how to effectively teach these topics to elementary students.

\subsection{Instructional Strategies}

Eight of the twelve preservice teachers reported that their pre-conceived instructional practices have changed significantly as a result of what they learned in each class session. Their responses focused on the future use of manipulatives and games, the structure of their lessons, using more effective questioning strategies including the use of wait time, differentiation of instruction and the pacing of lessons. When observed, all twelve preservice 
teachers included some type of partner work that provided an opportunity for students to work and learn from their peers' questions and suggestions. Students were guided in constructing their own thoughts on problem solving and encouraged to share their strategies in small group or whole-class discussion. In both whole-class and small group discussions students were engaged in questioning and explanation activities that lead to "doing" mathematics. Prior to the elementary methods course, twelve of the preservice teachers described their school math instruction as a "one size fits all" with the predominant strategy being the "tell, show and do" model. The preservice teachers shared how their teachers relied upon the textbook for the selection of what mathematics to teach, how to teach it, when to teach the concepts and the amount of time they devoted to teaching the specific topics. They reported that the mathematics they were doing involved completing numerous workbook pages/worksheets and with a focus on repetitive practice of procedures and everyone did the same assignment.

Eleven of the twelve, indicated how helpful the time provided for them to practice and/or work on developing open-ended questions with the goal being to encourage student-developed solutions to problems while planning for lessons. The classroom discussions observed occurred at various times during the lessons. Some were planned at the beginning of a lesson as the preservice teacher reviewed the previous day's work or prepared students for the lesson by reviewing previous lessons. In other classrooms, the whole-class discussion followed periods of the small-group center activities. All of these discussions provided opportunities for students to articulate their thinking and examine the thinking of their peers.

\subsection{Student Engagement}

With a better understanding of how to teach mathematics, all twelve of the preservice teachers shared that their instructional practices would look nothing like what they experienced as learners. One of the twelve preservice teachers used the term "transformative" to describe these changes. All twelve of the preservice teachers shared that they would engage students more in responding to challenging questions and math talks (peer discussions). They would use more interactive and engaging problems and instructional activities. One preservice teacher expressed how much she enjoyed "Fun Fridays". These days consisted of the use of many hands-on activities conducted in the classrooms where the students were allowed to choose the activity they wanted to participate in small groups playing math games and/or participating in challenging center activities, and would implement in her future classroom. All twelve of the preservice teachers shared how the math methods course helped them become better future teachers of math and has shown them that math class can be a fun learning environment. The inquiry-based instructional approaches made math fun and allowed the preservice teachers to see that math does not have to be something they should fear. Elementary students were also observed enjoying math. One preservice teacher commented on how her students cheered when they knew it was time for math and moaned when math time was over. They believe that their focus on student learning and their developing knowledge of effective assessment strategies enabled them to be strategic in the planning and pacing of math instruction. The only concerns expressed, was pertaining to organizing and managing the classroom for active hands-on learning. All preservice teachers expressed the importance of hands-on activities in positively shaping their views of math, as well as fostering their self-confidence. All shared that they were looking forward to teaching math, where before they had reservations, "butterflies" when thinking about math instruction.

\subsection{Struggling Students and Those with Special Needs}

All of the preservice teachers shared challenges of strategically grouping the students according to the learning needs identified and pairing with compatible working partners. All of the classrooms observed included those students identified with special needs in the small group activities. They were also paired with a partner for discussion questions. All students were grouped for the math center rotations. In one classroom observed, the Cooperating Teacher provided help for two students with Individualized Educational Plans (IEP).

Six of the twelve preservice teachers shared stories of frustration when working with struggling students not using the manipulatives correctly. Two of the six expressed appreciation for the Title I teachers who were present to provide additional help and extra hands for those students who struggled in math. Four of the preservice teachers observed, struggled keeping students on-task with use of manipulatives. Cooperating teachers stepped in to help with these students in all instances. One cooperating teacher removed a student from the group to work by himself. In other classrooms observed, the cooperating teachers joined the groups where the problems were present.

These same six preservice teachers shared the challenges of managing classroom behavior while instructing with manipulatives being used in the activities. One preservice teacher commented, "it seems to be much easier when we were learning about these activities and using them in our class, it is a different ball game in the real classroom with third graders". All of the preservice teachers commented on the successes they experienced with 
the grouping strategies used to place struggling students in groups along with the manipulatives chosen for instruction and how it increased overall student participation that resulted in learning.

Comments were also made about the paraprofessionals in the classrooms and how they provided one-on-one help for those students needing it. The paraprofessionals were observed restating instructions, providing prompting and cueing and guiding student discussions during the partner-pair-share activities. Behavior Management was observed as a challenge for eight of the twelve at times involving manipulatives. Four of the eight were able to curtail the problems and get the students back on track, the other four either ignored the problems, moved students from groups or cooperating teacher stepped in to help.

\section{Conclusion}

After completion of the math methods course and clinical experience in elementary classrooms, the preservice teachers' conversations of math teaching changed from describing a teacher in a classroom much like a conductor of an orchestra, all that can be seen is a person waving their arms -to what cannot be seen under the stage- all the preparation to get to the beautiful music. The clinical experience opened the preservice teachers' eyes on the actual practice of teaching mathematics in an elementary classroom. The reality of the minute-to-minute implementation of instruction, classroom management with the use of manipulatives, and orchestrating multiple opportunities to practice what was learned in class, proved to be a challenge for most of the preservice teachers observed. The findings of this study indicate that the preservice teachers still perceived themselves to be more effective mathematics teachers, with greater knowledge of mathematics and how to teach mathematics after participating in the elementary methods course in spite of the classroom challenges they experienced. They reported an increase in confidence of their ability to teach mathematics. Learning the course content was reported as easy with the instructional practices demonstrated in class. In addition, the preservice teachers also shared that the math content was easier to teach for conceptual understanding when taught to grade level students. They also observed positive changes in the elementary students' achievement and attitudes toward mathematics. The preservice teachers shared personal reflections on how the positive changes that were occurring in the teaching and learning of mathematics became the perceptions they developed about their self-efficacy. As students became more successful and enthusiastic about learning mathematics, the preservice teachers' self- efficacy increased.

The overall result of this study, suggests that through a mathematics course designed on the principles of developing preservice teachers' knowledge of mathematics content and constructivist pedagogy, the study showed gains in preservice teachers' self-efficacy and an increase in positive attitudes towards math instruction. Preservice teachers need to possess a high self-efficacy for teaching mathematics and the tools to meet the challenge of reform-based teaching will require teachers to have deep insights about mathematics, about students as learners of mathematics and about pedagogy that will support students' learning. After all, the future is only as good as what we put out there as teachers.

\section{References}

Ball, D. L. (1990). The Mathematical Understandings that prospective teachers bring to teacher education. Elementary School Journal, 90(4), 449-466. https://doi.org/10.1086/461626

Ball, D. L. (1996). Teacher learning and the mathematics reform: What we think we know and what we need to learn. Phi Delta Kappan, 77(7), 500-508.

Ball, D. L., \& Bass, H. (2000). Interweaving content and pedagogy in teaching and learning to teach: Knowing and using mathematics. In J. Boaler (Ed.), Multiple Perspectives on the teaching and learning of mathematics (pp. 83-104). Westport, CT: Ablex.

Ball, D. L., Hill, H. C., \& Bass, H. (2005). Knowing mathematics for teaching. American Educator, 14-46.

Ball, D. L., Thames, M. H., \& Phelps, G. (2008). Content knowledge for teaching: What makes it special? Journal of Teacher Education, 59(5), 389-407. https://doi.org/10.1177/0022487108324554

Bandura, A. (1977). Self-efficacy: Toward a Unify Theory of Behavioral Change. Psychological Review, 84(3), 191-215. https://doi.org/10.1037/0033-295X.84.2.191

Bandura, A. (1993). Perceived self-efficacy in cognitive development and functioning. Educational Psychologist, 28(2), 117-148. https://doi.org/10.1207/s15326985ep2802_3

Battista, M. T. (1999). The mathematical miseducation of America's youth: Ignoring research and scientific study in education. Phi Delta Kappan, 80(6), 424-433. Retrieved from http://www.kappanmagazine.org 
Burns, M. (2007). About teaching mathematics: A K-8 resource (3rd ed.). Sausalito, CA: Math Solutions.

Bybee, R. W. (2009). The BSCS 5 E Instructional Model and $21^{S T}$ Century Skills. The National Academies Board on Science Education. Retrieved from http://sites.nationalacademies.org/cs/groups/dbassesite/documents/webpage/dbasse_073327.pdf

Cady, J., \& Rearden, K. (2007). Preservice teachers' beliefs about knowledge, mathematics and science. School Science and Mathematics, 107(6), 236-245. https://doi.org/10.1111/j.1949-8594.2007.tb18285.x

Carpenter, T., Fennema, E., \& Franke, M. (1996). Cognitively Guided Instruction: A Knowledge Base for Reform in Primary Mathematics Instruction. The Elementary School Journal, 97(1), 3-20. https://doi.org/10.1086/461846

Çaycı, B. (2011). The relationship between the elementary teacher candidates' teacher efficacy and their attitudes towards the profession of teaching. Education, 132(2), 402-418.

Chester, M. D., \& Beaudin, B. Q. (1996). Efficacy beliefs of newly hired teachers in urban schools. American Educational Research Journal, 33(1), 233-257. https://doi.org/10.3102/00028312033001233

Cochran-Smith, M., \& Zeichner, K. M. (2005). Studying teacher education: The report of the AERA Panel on Research and Teacher Education. Mahwah, NJ: Lawrence Erlbaum.

Cramer, K., Post T., \& delMas, R. (2002). Initial fraction learning by fourth and fifth grade students: A comparison of the effects of using commercial curricula with the effects of using the rational number project curriculum. Journal for Research in Mathematics Education, 33(2), 11-144. https://doi.org/10.2307/749646

Dacey, L., \& Polly, D. (2014). CCSSM, The Big Picture. Teaching Children Mathematics, 18(6), 378-383. https://doi.org/10.5951/teacchilmath.18.6.0378

Darling-Hammond, L., \& Ball, D. L. (1998). Teaching for high standards: What policymakers need to know and be able to do. National Commission on Teaching and America's Future. Retrieved from http://www.nctaf.org/documents/teaching-high-standards.pdf

Darling-Hammond, L., \& Ball, D. L. (2004). Teaching for high standards: What policymakers need to know and be able to do (CPRE Joint Series Report No. JRE-04). Philadelphia: CPRE Publications, University of Pennsylvania. Retrieved from http://www.nctaf.org/documents/teaching-high-standards.pdf

Denzin, N. K., \& Lincoln, Y. S. (2005). The Sage Handbook of Qualitative Research. Sage Publishers: Thousand Oaks.

Enochs, L. G., Smith, P. L., \& Huinker, D. (2000). Establishing factorial validity of the mathematics teaching efficacy beliefs instrument. School Science and Mathematics, 100, 194-202. https://doi.org/10.1111/j.1949-8594.2000.tb17256.x

Franke, M. L., \& Kazemi, E. (2001). Learning to teach mathematics: Focus on student thinking. Theory into Practice, 40(2), 102-109. https://doi.org/10.1207/s15430421tip4002_4

Gersten, R., Beckmann, S., Clarke, B., Foegen, A., Marsh, L., Star, J. R., \& Witzel, B. (2009). Assisting students struggling with mathematics: Response to intervention (RtI) for elementary and middle schools (NCEE 2009-4060). Washington, DC: National Center for Education Evaluation and Regional Assistance, Institute of Education Sciences, U.S. Department of Education.

Goos, M. (2004). Learning mathematics in a classroom community of inquiry. Journal for Research in Mathematics Education, 35(4), 258-291. https://doi.org/10.2307/30034810

Harper, N., \& Daane, C. (1998). Causes and reductions of math anxiety in preservice elementary teachers. Action in Teacher Education, 19, 29-38. https://doi.org/10.1080/01626620.1998.10462889

Harris, M. B. (1997). Basic statistics for behavioral science research (2nd ed.). Needham Heights, MA: Allyn \& Bacon.

Herron, J. (2010). Implementation of Technology in an Elementary Mathematics Lesson: The Experiences of Preservice Teachers at One University. SRATE Journal, 19(1), 22-29.

Hill, H. C., \& Ball, D. L. (2008). Unpacking pedagogical content knowledge: Conceptualizing and measuring teachers' topic-specific knowledge of students. Journal for Research in Mathematics Education, 39(4), $372-400$. 
Hocutt, A. M. (1996). Effectiveness of special education: Is placement the critical factor? The Future of Children, 6(1), 77-102. https://doi.org/10.2307/1602495

Kelly, C. A. (2006). Using Manipulatives in Mathematical Problem Solving: A Performance-Based Analysis. The Mathematics Enthusiast, 3(2). Retrieved from http://scholarworks.umt.edu/tme/vol3/iss2/6

Kersting, N. B., Givvin, K. B., Thompson, B. J., Santagata, R., \& Stigler, J. W. (2012). Measuring Usable Knowledge: Teachers' Analyses of Mathematics Classroom Videos Predict Teaching Quality and Student Learning. American Educational Research Journal, 49(3), 568-589. https://doi.org/10.3102/0002831212437853

Lambdin, D. V. (2003). Benefits of teaching through problem solving. In F. Lester (Ed.), Teaching mathematics through problem solving prekindergarten-grades 6 (pp. 3-13). Reston VA: NCTM.

Lamers, C. L., \& Stephens, A. C. (2006). Assessment Design: Helping Preservice Teachers Focus on Student Thinking. Teaching Children Mathematics, 13, 118-123.

Langdon, D., McKittrick, G., Beede, D., Khan, B., \& Doms, M. (2011). STEM: Good jobs now and for the future. Washington, DC: from http://www.esa.doc.gov/sites/news/documents/stemfinalyjuly14.pdf

Ma, L. (1999). Knowing and teaching elementary mathematics. Mahwah, NJ: Erlbaum.

Moyer, P. S. (2000). Communicating mathematically: Children's literature as a natural connection. The Reading Teacher, 54(3), 246-255.

Mullis, I., Martin, M. O., Foy, P., \& Hooper, M. (2015). TIMSS 2016 International Results in Mathematics. Retrieved May 17, 2017, from http:/timss2015.org/wp-content/uploads/filebase/full\%20pdfs/T15-International-Results-in-Mathematics-G rade-4.pdf

Murphy, S. J. (1999). Learning math through stories. School Library Journal, 45(3), 122-123.

National Center for Educational Statistics. (2015). National Assessment of Educational Progress. Washington, D. C.: United States Department of Education Institute of Education Sciences. Retrieved May 17, 2017, from $\mathrm{http}: / /$ nces.ed.gov/NATIONSREPORTCARD

National Council of Teachers of Mathematics. (1991). Professional Standards for Teaching Mathematics, Reston, VA: Author.

National Council of Teachers of Mathematics. (2000). Principles and Standards for School Mathematics: A Guide for Mathematicians Reston, VA: Author.

National Research Council. (2001). Adding it up: Helping children learn mathematics. In J. Kilpatrick, J. Swafford, \& B. Findell (Eds.), Mathematics Learning Study Committee, Center for Education, Division of Behavioral and Social Sciences and Education. Washington, D. C.: National Academy Press.

Newton, K. J., Evans, B. R., Leonard, J., \& Eastburn, J. A. (2012). Preservice elementary teachers' mathematics content knowledge and teacher efficacy. School Science and Mathematics, 112(5), 289-299. https://doi.org/10.1111/j.1949-8594.2012.00145.x

Nicholls, J. (1984). Achievement Motivation: Conceptions of Ability, Subjective Experience, Task Choice, and Performance. Psychological Review, 91(3), 328-346. https://doi.org/10.1037/0033-295X.91.3.328

Pajares. (2002). Overview of social cognitive theory and of self-efficacy. Retrieved from http://www.emory.edu/EDUCATION/mfp/eff.html

Puchner, L., Taylor, A., O'Donnell, B., \& Fick, K. (2008). Teacher learning and mathematics manipulatives: A collective case study about teacher use of manipulatives in elementary and middle school mathematics lessons.

Putnam, R. T., \& Borko, H. (2006). What Do New Views of Knowledge and Thinking Have to Say about Research on Teacher Learning? Educational Researcher, 29(1), 4-15. https://doi.org/10.3102/0013189X029001004

Richards, L. (2005). Handling qualitative data. London: Sage.

Riggs, I., \& Enochs, L. G. (1990). Toward the development of an elementary teachers' science teaching efficacy belief instrument. Science Education, 74(6), 625-637. https://doi.org/10.1002/sce.3730740605 
Rizzo, N. (2010). Formative Assessment-A Practical Approach. Using Good Questions and Tasks to Assess Student. Understanding. NCTM Annual Conference, San Diago, CA. Retrieved from http://mathsolutions.com/wpcontent/uploads/10_NCTM_NR_Assessment.pdf

Rowan, B., Harrison, D. M., \& Hayes, A. (2004). Using instructional logs to study mathematics curriculum and teaching in the early grades. Elementary School Journal, 105, 103-127. https://doi.org/10.1086/428812

Savage, S. (2005). Examining Perceptions of Mathematics Teaching Effectiveness Among Elementary Preservice Teachers with Differing Levels of Mathematics Teacher Efficacy. Retrieved June 25, 2017, from http://www.redorbit.com/news/education/175196/examining_perceptions_of_mathematics_teaching_effecti veness_among_elementary_preservice_teachers/

Sowell, E. (1989). Effects of manipulative materials in mathematics instruction. Journal for Research in Mathematics Education, 20, 498-505. https://doi.org/10.2307/749423

Steffe, L., \& D’Ambrosio, B. (1995). Toward a working model of constructivist teaching: A reaction to Simon. Journal for Research in Mathematics Education, 26, 146-159. https://doi.org/10.2307/749206

Stein, M. K., \& Bovalino, J. W. (2001). Manipulatives: One piece of the puzzle. Mathematics Teaching in the Middle School, 6(6), 356-359.

Stephens, A. C., \& Lamers, C. L. (2006). Assessment Design: Helping Preservice Teachers Focus on Student Thinking. Teaching Children Mathematics, 118-123.

Stigler, J. W., Gonzales, P., Kawanaka, T., Knoll, S., \& Serrano, A. (1999). The TIMSS videotape classroom study: Methods and findings from an exploratory research project on eighth-grade mathematics instruction in Germany, Japan, and the United States. Washington, D.C.: National Center for Educational Statistics.

Swars, S. L., Daane, C. J., \& Giesen, J. (2006). Mathematics anxiety and mathematics teacher efficacy: What is the relationship in elementary preservice teachers? School Science and Mathematics, 106(7), 306-315. https://doi.org/10.1111/j.1949-8594.2006.tb17921.x

Thomas, D. R. (2006). A general inductive approach for analyzing qualitative evaluation data. American Journal of Education, 27, 237-246. https://doi.org/10.1177/1098214005283748

Tschannen-Moran, M., Woolfolk Hoy, A., \& Hoy, W. K. (1998). Teacher efficacy: Its meaning and measure. Review of Educational Research, 68(2), 202-248. https://doi.org/10.3102/00346543068002202

Turner, E., Drake, C., McDuffie, A., Aguirre, J., Bartell, T., \& Foote, M. (2012). Promoting Equity in Mathematics Teacher Preparation: A Framework for Advancing Teacher Learning of Children's Multiple Mathematical Knowledge Bases. Journal of Mathematics Teacher Education, 15(1), 67-82. https://doi.org/10.1007/s10857-011-9196-6

U.S. Department of Education, Institute of Education Sciences (DOE IES). (2007). Highlights from the Trends in International Mathematics and Science Study (TIMSS) 2003 (NCES No. 2005-005). Washington, DC: Author.

U.S. Department of Education, Institute of Education Sciences (DOE IES). (2009). The nation's report card: Mathematics 2009 (NCES No. 2010451). Washington, DC: Author.

Van den Berg, R. (2002). Teacher's meaning regarding educational practice. Review of Educational Research, 72(4), 577-625. https://doi.org/10.3102/00346543072004577

Vinson, B. M. (2001). A Comparison of Preservice Teachers' Mathematics Anxiety Before and After a Methods Class Emphasizing Manipulatives. Early Childhood Education Journal, 29(2), 89-94. https://doi.org/10.1023/A:1012568711257

Ware, H., \& Kitsantas, A. (2007). Teacher and collective efficacy beliefs as predictors of professional commitment. The Journal of Educational Research, 100(5), 303-310. https://doi.org/10.3200/JOER.100.5.303-310

Weiss, I. R., Banilower, E. R., McMahaon, K. C., \& Smith, P. S. (2001). Report of the 2000 national survey of science and mathematics education. Retrieved July 3, 2016, from http://horizon-research.com

Weiss, I. R., Pasley, J. D., Smith, S., Banilower, E. R., \& Heck, D. J. (2003). Looking inside the classroom: A study of K-12 mathematics and science education in the United States. Retrieved May 23, 2016, from http://horizon-research.com 
Wilson, S. M., Floden, R. E., \& Ferrini-Mundy, J. (2002). Teacher preparation research: An insider's view from the outside. Journal of Teacher Education, 53(3), 190-204. https://doi.org/10.1177/0022487102053003002

Woolfolk, A. E., \& Hoy, W. K. (1990). Prospective teachers' sense of efficacy and beliefs about control. Journal of Educational Psychology, 82(1), 81-91. https://doi.org/10.1037/0022-0663.82.1.81

\section{Copyrights}

Copyright for this article is retained by the author(s), with first publication rights granted to the journal.

This is an open-access article distributed under the terms and conditions of the Creative Commons Attribution license (http://creativecommons.org/licenses/by/4.0/). 